\title{
Antituberculosis activity, phytochemical identification of Costus speciosus (J. Koenig) Sm., Cymbopogon citratus (DC. Ex Nees) Stapf., and Tabernaemontana coronaria (L.) Willd. and their effects on the growth kinetics and cellular integrity of Mycobacterium tuberculosis H37Rv
}

Suriyati Mohamad ${ }^{1 *}$ D, Nur Najihah Ismail ${ }^{1}$, Thaigarajan Parumasivam², Pazilah Ibrahim², Hasnah Osman ${ }^{3}$ and Habibah A. Wahab ${ }^{2}$

\begin{abstract}
Background: Costus speciosus, Cymbopogon citratus, and Tabernaemontana coronaria are herbal plants traditionally used as remedies for symptoms of tuberculosis (TB) including cough. The aims of the present study were to evaluate the in vitro anti-TB activity of different solvent partitions of these plants, to identify the phytochemical compounds, and to assess the effects of the most active partitions on the growth kinetics and cellular integrity of the tubercle organism.

Methods: The in vitro anti-TB activity of different solvent partitions of the plant materials was determined against M. tuberculosis H37Rv using a tetrazolium colorimetric microdilution assay. The phytochemical compounds in the most active partition of each plant were identified using gas chromatography-mass spectrometry (GC-MS) analysis. The effects of these partitions on the growth kinetics of the mycobacteria were evaluated over 7-day treatment period in a batch culture system. Their effects on the mycobacterial cellular integrity were observed under a scanning electron microscope (SEM).
\end{abstract}

Results: The respective n-hexane partition of C. speciosus, C. citratus, and T. coronaria exhibited the highest anti-TB activity with minimum inhibitory concentrations (MICs) of $100-200 \mathrm{\mu g} / \mathrm{mL}$ and minimum bactericidal concentration (MBC) of $200 \mu \mathrm{g} / \mathrm{mL}$. GC-MS phytochemical analysis of these active partitions revealed that majority of the identified compounds belonged to lipophilic fatty acid groups. The active partitions of C. speciosus and T. coronaria exhibited high cidal activity in relation to time, killing more than $99 \%$ of the cell population. SEM observations showed that these active plant partitions caused multiple structural changes indicating massive cellular damages. (Continued on next page)

\footnotetext{
* Correspondence: suri@usm.my

'School of Biological Sciences, Universiti Sains Malaysia, 11800 Minden, Pulau

Pinang, Malaysia

Full list of author information is available at the end of the article
} 
(Continued from previous page)

Conclusions: The $n$-hexane partition of the plant materials exhibited promising in vitro anti-TB activity against $M$. tuberculosis H37Rv. Their anti-TB activity was supported by their destructive effects on the integrity of the mycobacterial cellular structure.

Keywords: Costus speciosus, Cymbopogon citratus, Tabernaemontana coronaria, Antituberculosis activity, Phytochemical identification, Growth kinetics, Cellular integrity

\section{Background}

The scourge of $M$. tuberculosis, the etiologic agent of tuberculosis (TB) causes one of the world's most devastating global health crises [1]. In 2015, the World Health Organisation (WHO) estimated that about 10.4 million people contracted TB and 1.4 million people died from this disease worldwide [2]. Even though TB mortality rate fell by $22 \%$ between 2000 and 2015, the inexorable threats arising from resistant and persistent TB are of major concern $[2,3]$. With the limited presence of new anti-TB drugs, the global burden of TB continues to loom with an enormous toll in morbidity and mortality [4]. Therefore, the most urgent goal of TB chemotherapy is to develop highly active and low-cost drugs, which are readily produced $[5,6]$.

Among the possibilities to discover for potential new drugs are to prospect for these agents from natural resources such as plants. The primary advantages of using plants are that, they are inexhaustible sources of natural drugs as they provide a wealth of small molecules with drug-like properties and incredible structural diversity [7]. In addition, the profound therapeutic benefits of plantderived medicines can mitigate many of the side effects that are often associated with synthetic drugs [8]. Ideally, the natural new drugs should also be more affordable and exhibit high bactericidal capacity. A high bactericidal capacity will result in a rapid decrease in the mycobacterial load and renders the patients less infectious [9].

As part of a continuous research to discover new potent and cheaper anti-TB agents from Malaysian ethnobotanical plants, we investigated the anti-TB potential of Costus speciosus (J. Koenig) Sm., Cymbopogon citratus (DC.) Stapf., and Tabernaemontana coronaria (Jacq.) Willd. since they are traditionally used as remedies to cure various respiratory diseases including cough [10-12]. These three plants are widely distributed in tropical countries and are commonly cultivated as garden herbs for use in cooking and for medicinal purposes. C. speciosus is an ornamental herb, which belongs to the family Coastaceae. Its common name is Malay or crepe ginger and its local name is setawar halia. C. citratus is a famous culinary herb, which is a member of the family Gramineae. Its common name is lemon grass and its local name is serai. The synonym of $T$. coronaria is $T$. divaricata (L.) R.Br. ex Roem. \& Schult and it belongs to the family Apocynaceae. Its common name is crepe jasmine and its local name is akar susun kelapa. Many publications have reviewed and reported a variety of pharmacological properties of these medicinal plants including antibacterial, antifungal, anticough, antioxidant, antihelminthic, and antipneumonia [13-15]. In a previous preliminary study, we reported that the methanol extracts of C. speciosus and T. coronaria exhibited promising anti-TB activity with minimum inhibitory concentration (MIC) of $800 \mu \mathrm{g} / \mathrm{mL}$ against M. tuberculosis H37Rv, supporting their traditional uses in the treatment of $\mathrm{TB}$ [16]. In the present study, we investigated the in vitro anti-TB activity of different partitions of C. speciosus, $C$. citratus, and $T$. coronaria with emphasis on their effects on the growth kinetics and cellular integrity of the tubercle organism.

\section{Methods}

\section{Collection and identification of plant materials}

The plant materials were collected from identified areas in the northern states of Pulau Pinang and Kedah, West Malaysia. The plant species were authenticated by the Herbarium Unit, School of Biological Sciences, Universiti Sains Malaysia, where voucher specimens were deposited with designated numbers $11,435,11,152$, and 11,429 for $C$. speciosus, $C$. citratus, and $T$. coronaria, respectively. The plant materials (stems and flowers for C. speciosus, stems and rhizomes for $C$. citratus, and leaves for $T$. coronaria) were cleaned, dried in an oven at $40{ }^{\circ} \mathrm{C}$, and pulverised into minute pieces.

\section{Partition preparation}

Initial extraction of the pulverised dried plant materials was carried out by exhaustive maceration in $80 \%$ methanol for two to seven days at ambient temperature $\left(26-27^{\circ} \mathrm{C}\right)$. The crude methanol extracts were filtered (Whatman filter paper No. 1, England), and partially concentrated under reduced pressure at $40{ }^{\circ} \mathrm{C}$ using a rotary evaporator (Eyela, Japan). Then, the methanol extracts were sequentially partitioned using five solvents of different polarities: n-hexane, chloroform, ethyl acetate, and nbutanol (Merck, Germany). The partitioning process was carried out following the procedures as described previously [17] with minor modifications. Initially, 10-15 g of each crude methanol extract was dissolved completely in $200 \mathrm{~mL}$ mixture of methanol and distilled water $(3: 17, v / \mathrm{v})$ to produce an aqueous crude methanol extract. Then, an 
equal volume $(200 \mathrm{~mL})$ of $\mathrm{n}$-hexane was added into this solution and shaken until well mixed. The mixture was poured into a separation funnel and swirled gently to ensure complete mixture. The separation funnel stopper was removed for a while to relieve the vapour pressure produced from mixing of the organic solvents. The n-hexane phase was collected when two distinct layers were observed and the solvent was changed. This process was repeated three times. During each change, the suspension of aqueous crude methanol extract was topped-up with distilled water to maintain the volume of $200 \mathrm{~mL}$ before new $\mathrm{n}$-hexane solvent was added. The pooled $\mathrm{n}$-hexane partition was dried completely in an oven at $40{ }^{\circ} \mathrm{C}$, weighed, and stored at $4{ }^{\circ} \mathrm{C}$ prior to usage. The successive partitioning process was continued by replacing $n$-hexane with chloroform followed by ethyl acetate and n-butanol, consecutively. The final remaining extract from the aqueous crude methanol extract was labelled as aqueous partition. Stock solutions of the partitions were prepared at a concentration of $40 \mathrm{mg} / \mathrm{mL}$ in $100 \%$ dimethyl sulphoxide (DMSO). Prior to bioassay, working solutions of the partitions were prepared at a concentration of $3200 \mu \mathrm{g} / \mathrm{mL}(8 \%$ DMSO, $v / v$ ) by diluting the stock solutions in sterile distilled water. The working solutions were then sterilised by filtration using a cellulose membrane (Sartorius, Germany) of $0.22 \mu \mathrm{m}$ pore size.

\section{Preparation of Mycobacterium tuberculosis H37Rv inoculum}

The test organism, M. tuberculosis H37Rv ATCC 25618 was grown on Middlebrook (MB) 7H10 agar (Difco, USA) enriched with oleic acid, albumin, dextrose, and catalase (OADC) (Difco, USA) for 10 days at $37{ }^{\circ} \mathrm{C}$ in $8 \% \mathrm{CO}_{2}$. The inoculum for the determinations of MIC and minimum bactericidal concentration $(\mathrm{MBC})$ was prepared by suspending the 10-day old mycobacterial cells in $10 \mathrm{~mL}$ of MB7H9 broth (Difco, USA) enriched with albumin, dextrose, and catalase (ADC) (Difco, USA) and incubated for three days to attain log phase of growth. The turbidity of the cell culture was first adjusted to McFarland standard No. 1 (equivalent to approximately $3 \times 10^{7}$ colony forming units $(\mathrm{CFU}) / \mathrm{mL}$ ) and then was further diluted 1:20 in MB7H9-OADC broth to give a final inoculum concentration of approximately $1.5 \times 10^{7} \mathrm{CFU} / \mathrm{mL}$. A different inoculum was prepared for the growth kinetics study by suspending the 10-day old mycobacterial cells grown on MB7H10 agar in $10 \mathrm{~mL}$ of MB7H9-ADC broth and the turbidity of the cell suspension was immediately adjusted to McFarland standard No. 3, equivalent to a density of approximately $9 \times 10^{8} \mathrm{CFU} / \mathrm{mL}$. All procedures involving handling of the organism were carried out under very strict containment conditions in class $2^{+}$biosafety cabinets to eliminate biohazards.
Determination of minimum inhibitory concentration and minimum bactericidal concentration values of plant solvent partitions against Mycobacterium tuberculosis H37Rv

The determination of MIC value of the plant solvent partitions against $M$. tuberculosis $\mathrm{H} 37 \mathrm{Rv}$ were performed using a colorimetric tetrazolium microdilution assay based on the technique as described previously [18] and modified slightly as in our earlier report [16]. Each partition was tested in triplicates at least twice until reproducible results were consistently obtained. Briefly, $200 \mu \mathrm{L}$ of sterile distilled water was added into all outer perimeter wells of two sets of sterile 96-well microtitre plates (TPP, Germany) in duplicate to prevent dehydration during incubation. The microplates of Set 1 were for the determination of MIC and Set 2 were for the determination of MBC. Then, $100 \mu \mathrm{L}$ of MB7H9-OADC broth was added into all wells except the first test column of each microplate. A volume of $100 \mu \mathrm{L}$ of each partition working solution was then added into the wells in the first and second test columns in triplicates. By using a multi-channel pipette, a two-fold dilution series of the partition was made by initially transferring $100 \mu \mathrm{L}$ from the wells in the second to the third test columns. Control wells containing anti-TB drug, isoniazid and untreated control wells with no partition or drug were included in each microplate. Next, $100 \mu \mathrm{L}$ of $M$. tuberculosis $\mathrm{H} 37 \mathrm{Rv}$ inoculum was added into all wells. The test concentrations of the plant partitions ranged from 1600 to $50 \mu \mathrm{g} / \mathrm{mL}$. The test concentrations of isoniazid ranged from 1.25 to $0.039 \mu \mathrm{g} / \mathrm{mL}$. The final concentration of DMSO in the highest test concentration of partitions was $4 \% \mathrm{v} / \mathrm{v}$. Control experiments showed that $4 \%$ DMSO did not inhibit the growth of the mycobacterial cells. The microplates were sealed and incubated at $37{ }^{\circ} \mathrm{C}$ in $8 \% \mathrm{CO}_{2}$ for five days. On the 5 th day, $50 \mu \mathrm{L}$ of freshly prepared tetrazolium reagent mixture $(1: 1, \quad \mathrm{v} / \mathrm{v})$ of 3-(4,5-dimethylthiazol-2-yl)-2,5-diphenyltetrazolium bromide (MTT) (Sigma, USA) at a dilution of $1 \mathrm{mg} / \mathrm{mL}$ in absolute ethanol and sterile 10\% Tween 80 was added into the wells of microplates Set 1 and reincubated for another $24 \mathrm{~h}$. The results were read visually on the 6th day, whereby; a colour change from yellow to purple indicated growth. In living cells, MTT is reduced to an insoluble purple formazan by the mitochondrial dehydrogenases and reductases of the cells associated with the regulation of cell growth, proliferation, and differentiation $[19,20]$. Hence, the MIC was defined as the lowest partition concentration, which prevented the colour change of tetrazolium reagent from yellow to purple, at which visible growth was inhibited.

The determination of $\mathrm{MBC}$ value of the plant solvent partitions was performed based on the technique as described by the Clinical and Laboratory Standards Institute (CLSI) [21] with appropriate modifications. In continuation of the MIC determination, on the 6th day, a loopful 
of the culture broth from each test well in microplates Set 2 corresponding to the yellow well (no growth) in microplates Set 1 was streaked onto MB7H10-OADC agar plate in duplicates. The plates were sealed and incubated for 21 days. The CFU were observed and the MBC was defined as the lowest partition concentration, which prevented total growth of the mycobacteria, at which 99.9\% of the final inoculum was killed.

\section{Identification of phytochemical compounds in active n-hexane partitions}

As GC-MS technique is an ideal technique for the characterisation of volatile and semi-volatile organic compounds of plant origins in non-polar plant extracts [22], it was used to identify the compounds contained in the active n-hexane partition in this study. Besides, it is concise, efficient, and the automated system gives fast, reproducible, and effective results. The GC-MS analysis was performed at the National Poison Centre, Universiti Sains Malaysia following a standard operational protocol. Briefly, $3 \mathrm{mg}$ of the dried $\mathrm{n}$-hexane partition of each plant was dissolved in $0.1 \mathrm{~mL}$ of $\mathrm{n}$-hexane. One microlitre of each mixture was injected into the GC-MS system for the requisite analysis. The system consisted of a Hewlett Packard HP7890 GC (California, USA), an auto sampler, HP5979 mass selective detector, and MSD ChemStation (E.02.01.1177) software. The column was an HP-5MS fused silica capillary column $(30 \mathrm{~m} \times 0.25 \mathrm{~mm}$ i.d) with cross-linked $5 \%$ phenyl methyl siloxane $(0.25 \mu \mathrm{m}$ film thickness). The carrier gas was helium at $2.1 \mathrm{~mL} / \mathrm{min}$. The oven temperature was $50{ }^{\circ} \mathrm{C}$ and held for five minutes. The temperature was increased linearly at $25^{\circ} \mathrm{C}$ per minute to $300{ }^{\circ} \mathrm{C}$. The final temperature was held for $10 \mathrm{~min}$. The inlet and detector temperatures were both set at $280{ }^{\circ} \mathrm{C}$. Full scan mode was performed using electron ionisation at $70 \mathrm{eV}$. The total run time was $25 \mathrm{~min}$. The identification of the compounds was based on mass spectral matching $(>80 \%)$ with reference standards in the National Institute of Standards and Technology library (NIST Version 2.0, Oct 22, 2009) and by direct comparison with published data. Then the name, molecular weight, and structure of the compounds of the partitions were ascertained.

Evaluating the effects of active $n$-hexane partitions on the growth kinetics of Mycobacterium tuberculosis H37Rv

The active $\mathrm{n}$-hexane partitions of C. speciosus (MIC: $100 \mu \mathrm{g} / \mathrm{mL}$ ), C. citratus (MIC:200 $\mu \mathrm{g} / \mathrm{mL}$ ), and T. coronaria (MIC: $100 \mu \mathrm{g} / \mathrm{mL}$ ) were further evaluated to observe their time-dependent effects on the growth kinetics of $M$. tuberculosis $\mathrm{H} 37 \mathrm{Rv}$ using the growth study procedure in a batch culture system as described previously [23]. Briefly, $2 \mathrm{~mL}$ of the mycobacterial inoculum (approximate concentration of $9 \times 10^{8} \mathrm{CFU} / \mathrm{mL}$ ) was inoculated into five sets of culture bottles in duplicates containing $18 \mathrm{~mL}$ of MB7H9-OADC broth and 20 sterile glass beads ( $3 \mathrm{~mm}$ diameter) for easy mixture. The first three sets of culture bottles (Set 1 - Set 3) contained different test partitions at a final concentration of their respective MIC values. Set 4 contained control drug, isoniazid at its MIC of $0.078 \mu \mathrm{g} / \mathrm{mL}$, whereas, Set 5 served as a positive growth control without partition or drug. The culture bottles were incubated at $37{ }^{\circ} \mathrm{C}$ in $8 \%$ $\mathrm{CO}_{2}$ for seven days with gentle occasional swirling to prevent cellular aggregations, which could result in inaccurate counts. Samples were taken daily from the culture bottles for the colony counts using a modification of the Miles and Misra drop plate method [24]. Briefly, ten-fold serial dilutions of the culture samples were prepared in phosphate buffer saline (PBS) solution. A volume of $20 \mu \mathrm{L}$ of each diluent was dropped in triplicates onto two sets of MB7H10-OADC agar plates. The plates were allowed to dry at room temperature $\left(26-27^{\circ} \mathrm{C}\right)$, sealed and incubated at $37{ }^{\circ} \mathrm{C}$ in $8 \% \mathrm{CO}_{2}$ for 21 days. After incubation, the colonies were counted and the CFU per $\mathrm{mL}$ were calculated.

\section{Observing the effects of active $\mathrm{n}$-hexane partitions on the cellular integrity of Mycobacterium tuberculosis H37Rv}

The effects of $\mathrm{n}$-hexane partitions of $C$. speciosus, $C$. citratus, and $T$. coronaria at their respective MIC values on the integrity of the mycobacterial cells were observed under a scanning electron microscope (SEM). The cells were harvested from Day 3 of the study on the growth kinetics of M. tuberculosis H37Rv. This was so, because on Day 3, the effects on the cellular integrity could be observed on both viable and dead cells, based on the results obtained for the growth kinetics study. The Electron Microscope Unit, School of Biological Sciences, Universiti Sains Malaysia performed sample preparation for SEM observation following a standard protocol. Briefly, each sample of the treated mycobacterial cells in 7H9-OADC broth was centrifuged at $1850 \mathrm{~g}$ for five minutes. The supernatant was discarded and the pellet was resuspended in McDowell-Trump fixative solution prepared in 0.1 M PBS for at least two hours. The sample suspension was then centrifuged, supernatant discarded, and the pellet was washed with 0.1 M PBS twice and post-fixed in osmium tetroxide prepared in PBS for one hour. The sample was again centrifuged and washed with distilled water twice. The pellet was dehydrated through a series of $50 \%, 75 \%, 95 \%$, and $100 \%$ ethanol followed by hexamethyldisilazane (HMDS) for 10 min each. The pellet was centrifuged and resuspended after each ethanol change. Lastly, after HMDS dehydration, the pellet was centrifuged and HMDS was decanted. The vials containing the cells were placed in a desiccator to air-dry at room temperature $\left(26-27{ }^{\circ} \mathrm{C}\right)$. The dried cells were mounted onto a SEM specimen stub with a double-sided sticky tape and coated with gold. Then the cells were observed under 
Leo Supra 50VP Field Emission SEM equipped with Oxford INCA 400 energy dispersive X-ray microanalysis system (Carl-Zeiss, Germany). The effects of the plant partitions on the cellular integrity of $M$. tuberculosis were compared to the effects of the isoniazid-treated and untreated control cells.

\section{Results}

Minimum inhibitory concentration and minimum bactericidal concentration of plant solvent partitions against Mycobacterium tuberculosis H37Rv

The TB inhibitory and bactericidal activities of the plant partitions based on MIC and MBC values are shown in Table 1.

In this study, we interpreted positive anti-TB activity as any values of MIC $\leq 1600 \mu \mathrm{g} / \mathrm{mL}$, which was the highest test concentration. $\mathrm{MBC}$ was only determined for partitions with MIC $\leq 200 \mu \mathrm{g} / \mathrm{mL}$ (based on the general values of our unpublished data). As indicated by the results in Table 1, all the stem-flower partitions of C. speciosus exhibited varying anti-TB activity with MICs of 1600$100 \mu \mathrm{g} / \mathrm{mL}$. The highest activity was exhibited by $\mathrm{n}-$ hexane partition (MIC: $100 \mu \mathrm{g} / \mathrm{mL}$; MBC: $200 \mu \mathrm{g} / \mathrm{mL}$ ), followed by chloroform partition (MIC: $200 \mu \mathrm{g} / \mathrm{mL}$; MBC: $200 \mu \mathrm{g} / \mathrm{mL}$ ). The stem-rhizome partitions of C. citratus that exhibited anti-TB activity were n-hexane (MIC: $200 \mu \mathrm{g} / \mathrm{mL}$ ), chloroform, and ethyl acetate (MIC: $1600 \mu \mathrm{g} /$ $\mathrm{mL}$ ). $\mathrm{MBC}$ was determined for its $\mathrm{n}$-hexane partition but there was no cidal effect shown even at the highest test concentration of $1600 \mu \mathrm{g} / \mathrm{mL}$. All the leaf partitions of $T$. coronaria exhibited anti-TB activity with MICs of $100-1600 \mu \mathrm{g} / \mathrm{mL}$. The highest activity was also exhibited by $\mathrm{n}$-hexane partition (MIC: $100 \mu \mathrm{g} / \mathrm{mL}$; MBC: $200 \mu \mathrm{g} /$ $\mathrm{mL}$ ). The polar partitions of methanol, n-butanol and aqueous of these three plants exhibited poor or no activity against the mycobacterial cells. The untreated control wells consistently showed growth of the mycobacterial cells and the control drug, isoniazid exhibited consistent inhibition with MIC of $0.078 \mu \mathrm{g} / \mathrm{mL}$.

\section{Identification of phytochemical compounds in active $\mathrm{n}$-hexane partitions}

In this study, preliminary phytochemical analysis was carried out to identify the compounds that could be present in the most active partition of each plant. The compounds were characterised and identified by comparison of their mass fragmentation patterns with NIST database library and published data. Figure $1 \mathrm{a}-\mathrm{c}$ show the GC-MS chemometric profiles of n-hexane partition of $C$. speciosus, C. citratus, and T. coronaria, respectively. In general, each plant $\mathrm{n}$-hexane partition revealed a mixture of large number of phytochemicals that constituted of almost all volatile and semi-volatile organic compounds. These compounds represented different major phytochemical classes including sterol, phenol, diterpene, sesquiterpene, alkaloid, triterpenoid, fatty acid, and tocopherol. Table $2 \mathrm{a}-\mathrm{c}$ show the major compounds identified in each n-hexane partition of C. speciosus, C. citratus, and T. coronaria, respectively. Their molecular structures are shown in Fig. 2.

The GC-MS chemometric profile of C. speciosus stemflower n-hexane partition (Fig. 1a) revealed the presence of 261 different compounds, of which 54 were identified. Amongst the 54 identified compounds, hexadecanoic acid or palmitic acid or palmitinic acid; 9,12-octadecadienoic acid (Z,Z), methyl ester or methyl linoleate; hexadecanoic acid, methyl ester or palmitic acid, methyl ester; octadecanoic acid, methyl ester; lanost-8-en-3-ol (3ß); stigmast-4-en-3-one; pentadecanoic acid or pentadecylic acid; 7-ergostenol; and 2H-1-benzopyran-6-ol, 3,4-dihydro-2,8-dimethyl-2-(4,8,12-trimethyltridecyl-2R-2) constituted the major compounds in this partition (Table 2a, Fig. 2). The other 45 identified compounds were found in trace amounts of $\leq 1.0 \%$ of the total peak area. The GC-MS chemometric profile of C. citratus stem-rhizome $\mathrm{n}$-hexane partition (Fig. $1 \mathrm{~b}$ ) revealed the presence of 308 different compounds, of which 36 were identified. The eight major compounds with $\geq 1.0 \%$ of the total peak area were 9,12-octadecadienoic acid (Z,Z); stigmasterol; 7,10-octadecadienoic acid, methyl ester; $\gamma$ sitosterol; selina-6-en-4-ol; 5-cholestene-3-ol, 24-methyl;

Table 1 Minimum inhibitory concentration and minimum bactericidal concentration values of the plant solvent partitions against Mycobacterium tuberculosis H37Rv

\begin{tabular}{|c|c|c|c|c|c|c|c|c|c|c|c|c|c|c|c|}
\hline \multirow[t]{3}{*}{ Plants } & \multirow{3}{*}{$\begin{array}{l}\text { Local names/ } \\
\text { Traditional } \\
\text { uses }\end{array}$} & \multirow{3}{*}{$\begin{array}{l}\text { Herbarium } \\
\text { vouchers }\end{array}$} & \multirow{3}{*}{$\begin{array}{l}\text { Plant } \\
\text { parts }\end{array}$} & \multicolumn{12}{|c|}{ Plant partitions and MIC and MBC $(\mu \mathrm{g} / \mathrm{mL})$} \\
\hline & & & & \multicolumn{2}{|c|}{ Methanol } & \multicolumn{2}{|c|}{ n-Hexane } & \multicolumn{2}{|c|}{ Chloroform } & \multicolumn{2}{|c|}{ Ethyl acetate } & \multicolumn{2}{|c|}{ n-Butanol } & \multicolumn{2}{|c|}{ Aqueous } \\
\hline & & & & $\overline{\mathrm{MIC}}$ & $\overline{M B C}$ & $\overline{M I C}$ & $\mathrm{MBC}$ & $\overline{\mathrm{MIC}}$ & $\overline{M B C}$ & $\overline{M I C}$ & $\mathrm{MBC}$ & $\overline{M I C}$ & $\mathrm{MBC}$ & $\mathrm{MIC}$ & MBC \\
\hline $\begin{array}{l}\text { Costus speciosus (J. Koenig) } \\
\text { Sm. (Costaceae) }\end{array}$ & $\begin{array}{l}\text { Setawar halia/ } \\
\text { Cough }\end{array}$ & 11435 & Stem-flower & 800 & ND & 100 & 200 & 200 & 200 & 400 & ND & 1600 & ND & 1600 & ND \\
\hline $\begin{array}{l}\text { Cymbopogon citratus (DC. } \\
\text { ex Nees) Stapf. (Graminae) }\end{array}$ & Serai/Cough & 11152 & Stem-rhizome & $\mathrm{NI}$ & ND & 200 & NC & 1600 & ND & 1600 & ND & $\mathrm{Nl}$ & ND & $\mathrm{NI}$ & ND \\
\hline $\begin{array}{l}\text { Tabernaemontana coronaria } \\
\text { (L.) Willd. (Apocynaceae) }\end{array}$ & $\begin{array}{l}\text { Akar susun } \\
\text { kelapa/Cough }\end{array}$ & 11429 & Leaf & 800 & ND & 100 & 200 & 800 & ND & 800 & ND & 400 & ND & 1600 & ND \\
\hline
\end{tabular}

"NI": not showing inhibition even at the highest test concentration of $1600 \mu \mathrm{g} / \mathrm{mL}$. "NC": not showing cidal effect even at the highest test concentration of $1600 \mu \mathrm{g} / \mathrm{mL}$. "ND": $\mathrm{MBC}$ not determined. All positive control wells showed bacterial growth. Negative growth control drug, isoniazid exhibited consistent $\mathrm{MIC}$ and $\mathrm{MBC}$ values of $0.078 \mu \mathrm{g} / \mathrm{mL}$ 


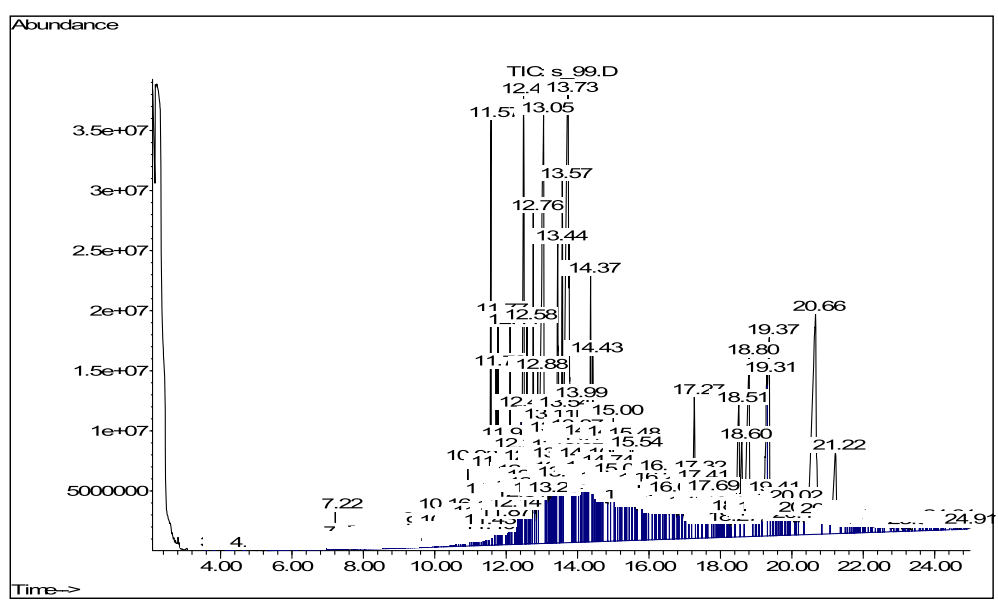

a. Cymbopogon citratus (stem-rhizome) n-hexane partition

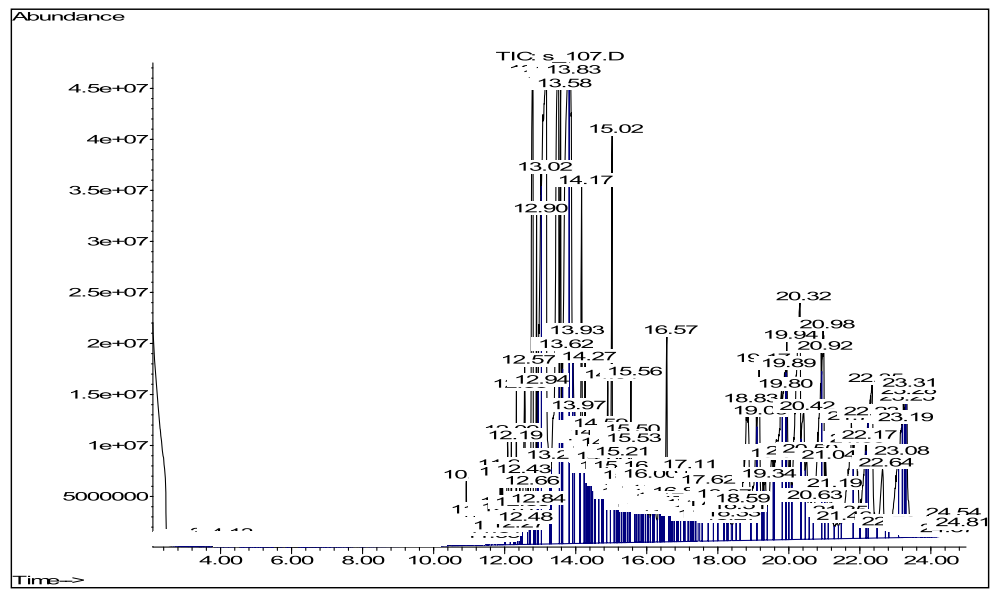

b. Costus speciosus (stem-flower) n-hexane partition

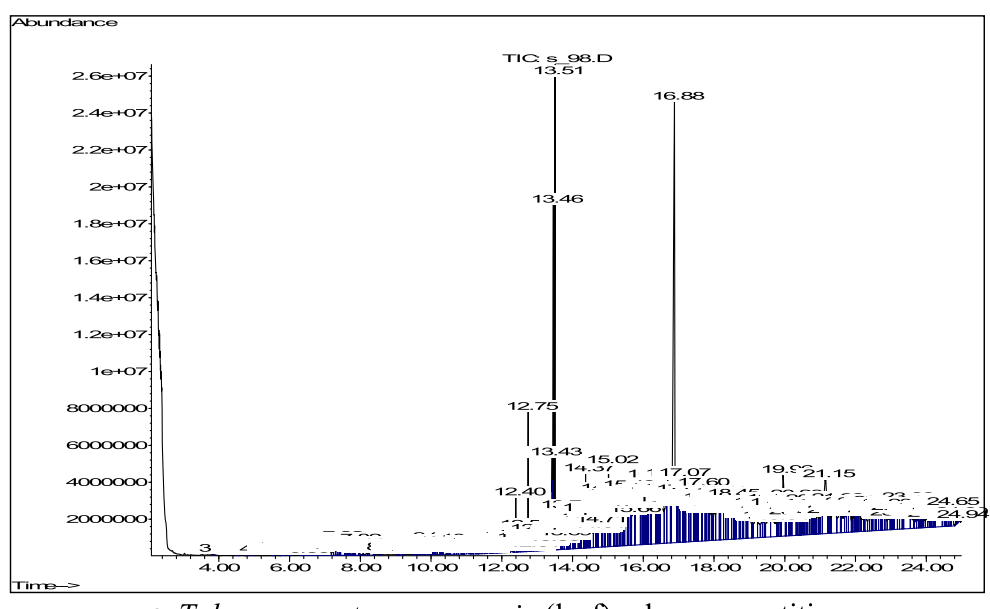

c. Tabernaemontana coronaria (leaf) n-hexane partition

Fig. 1 a-c Gas chromatography-mass spectrometry chemometric profiles of plant n-hexane partitions

cyclooctacosane; and hexadecanoic acid, methyl ester (Table 2b, Fig. 2). Lastly, the GC-MS chemometric profile of T. coronaria leaf $n$-hexane partition (Fig. 1c) revealed the presence of 323 different compounds, of which 31 were identified. Of these 31 compounds, ibogamine18-carboxylic acid, 12-methoxy, methyl ester; phytol; 9,12,15-octadecatrien-1-ol (Z,Z,Z); 12-oleanen-3-yl acetate, $(3 \alpha)$; ibogaine; vitamin E; 2H-1-benzopyran-6-ol, 3,4- 
Table 2 a-c Major phytochemical compounds identified in the active plant n-hexane partitions by gas chromatography-mass spectrometry chemometric profiling

\begin{tabular}{|c|c|c|c|c|c|c|c|c|c|}
\hline No. & $\begin{array}{l}\text { Retention } \\
\text { time (min) }\end{array}$ & Peak area & $\begin{array}{l}\% \text { of total } \\
\text { peak area }\end{array}$ & Name of compound & $\begin{array}{l}\text { Library } \\
\text { match (\%) }\end{array}$ & NIST No. & CAS No. & $\begin{array}{l}\text { Molecular } \\
\text { formula }\end{array}$ & $\begin{array}{l}\text { Molecular } \\
\text { weight }\end{array}$ \\
\hline \multicolumn{10}{|c|}{ a Costus speciosus (stem-flower) n-hexane partition ${ }^{a}$} \\
\hline 1 & 12.94 & $2.150 . E+08$ & 7.37 & $\begin{array}{l}\text { Hexadecanoic acid or n-Hexadecanoic } \\
\text { acid or Palmitic acid or Palmitinic acid }\end{array}$ & 95 & 151,973 & $57-10-3$ & $\mathrm{C}_{16} \mathrm{H}_{32} \mathrm{O}_{2}$ & 256 \\
\hline 2 & 13.514 & $3.480 . E+09$ & 7.25 & $\begin{array}{l}\text { 9,12-Octadecadienoic acid }(Z, Z) \text {, methyl } \\
\text { ester or Linoleic acid, methyl ester or } \\
\text { Methyl linoleate }\end{array}$ & 99 & 233,849 & $112-63-0$ & $\mathrm{C}_{19} \mathrm{H}_{34} \mathrm{O}_{2}$ & 294 \\
\hline 3 & 12.793 & $1.560 . E+09$ & 2.68 & $\begin{array}{l}\text { Hexadecanoic acid, methyl ester or } \\
\text { Methyl palmitate or Palmitic acid, } \\
\text { methyl ester }\end{array}$ & 99 & 158,970 & $112-39-0$ & $\mathrm{C}_{17} \mathrm{H}_{34} \mathrm{O}_{2}$ & 270 \\
\hline 4 & 13.577 & $9.940 . E+08$ & 1.71 & $\begin{array}{l}\text { Octadecanoic acid, methyl ester or } \\
\text { Stearic acid, methyl ester or Methyl } \\
\text { stearate }\end{array}$ & 98 & 79,123 & $112-61-8$ & $\mathrm{C}_{19} \mathrm{H}_{38} \mathrm{O}_{2}$ & 298 \\
\hline 5 & 19.165 & $9.070 . E+08$ & 1.56 & Lanost-8-en-3-ol, (3ß) & 91 & 253,595 & $79-62-9$ & $\mathrm{C}_{30} \mathrm{H}_{52} \mathrm{O}$ & 428 \\
\hline 6 & 20.985 & $8.240 . E+08$ & 1.42 & Stigmast-4-en-3-one & 95 & 17,165 & $1058-61-3$ & $\mathrm{C}_{29} \mathrm{H}_{48} \mathrm{O}$ & 412 \\
\hline 7 & 12.569 & $6.730 . E+08$ & 1.16 & $\begin{array}{l}\text { Pentadecanoic acid or Pentadecylic } \\
\text { acid }\end{array}$ & 99 & 63,741 & $1002-84-2$ & $\mathrm{C}_{15} \mathrm{H}_{30} \mathrm{O}_{2}$ & 242 \\
\hline 8 & 19.095 & $6.670 . E+08$ & 1.15 & 7-Ergostenol & 86 & 253,005 & $116,179-22-7$ & $\mathrm{C}_{28} \mathrm{H}_{48} \mathrm{O}$ & 400 \\
\hline 9 & 16.567 & $5.880 . E+08$ & 1.01 & $\begin{array}{l}\text { 2H-1-Benzopyran-6-ol, 3,4-dihydro-2,8- } \\
\text { dimethyl-2-(4,8,12-trimethyltridecyl)-, } \\
{\left[2 \mathrm{R}-\left[2 \mathrm{R}^{*}\left(4 \mathrm{R}^{*}, 8 \mathrm{R}^{*}\right)\right]\right]-}\end{array}$ & 98 & 151,380 & 119-13-1 & $\mathrm{C}_{27} \mathrm{H}_{46} \mathrm{O}_{2}$ & 402 \\
\hline \multicolumn{10}{|c|}{ b Cymbopogon citratus (stem-rhizome) n-hexane partition ${ }^{\mathrm{b}}$} \\
\hline 1 & 13.731 & 2.852.E +08 & 9.16 & $\begin{array}{l}\text { 9,12-Octadecadienoic acid }(Z, Z) \text { or } \\
\text { Linoleic acid }\end{array}$ & 93 & 229,327 & $60-33-3$ & $\mathrm{C}_{18} \mathrm{H}_{32} \mathrm{O}_{2}$ & 280 \\
\hline 2 & 18.808 & 8.335.E + 08 & 2.68 & $\begin{array}{l}\text { Stigmasterol or Sigmasta-5,22-dien- } \\
\text { 3-ol, }(3 \beta, 22 \mathrm{E})\end{array}$ & 90 & 251,057 & $83-48-7$ & $\mathrm{C}_{29} \mathrm{H}_{48} \mathrm{O}$ & 412 \\
\hline 3 & 13.444 & $6.416 . E+08$ & 2.06 & 7,10-Octadecadienoic acid, methyl ester & 95 & 35,764 & $56,554-24-6$ & $\mathrm{C}_{19} \mathrm{H}_{34} \mathrm{O}_{2}$ & 294 \\
\hline 4 & 19.368 & 5.734.E+ 08 & 1.84 & $\begin{array}{l}\text { Y-Sitosterol or Clionasterol or Stigmast- } \\
\text { 5-en-3-ol, }(3 \beta)\end{array}$ & 99 & 151,558 & $83-47-6$ & $\mathrm{C}_{29} \mathrm{H}_{50} \mathrm{O}$ & 414 \\
\hline 5 & 11.575 & $7.538 . E+08$ & 1.73 & Selina-6-en-4-ol & 94 & 140,232 & NA & $\mathrm{C}_{15} \mathrm{H}_{26} \mathrm{O}$ & 222 \\
\hline 6 & 18.514 & 4.958.E + 08 & 1.59 & 5-Cholestene-3-ol, 24-methyl & 99 & 214,174 & NA & $\mathrm{C}_{28} \mathrm{H}_{48} \mathrm{O}$ & 400 \\
\hline 7 & 17.274 & 3.632.E + 08 & 1.17 & Cyclooctacosane & 95 & 72,382 & $297-24-5$ & $\mathrm{C}_{28} \mathrm{H}_{56}$ & 392 \\
\hline 8 & 12.758 & $9.362 . E+08$ & 1.16 & $\begin{array}{l}\text { Hexadecanoic acid, methyl ester } \\
\text { or Methyl palmitate or Palmitic } \\
\text { acid, methyl ester }\end{array}$ & 98 & 158,970 & 112-39-0 & $\mathrm{C}_{17} \mathrm{H}_{34} \mathrm{O}_{2}$ & 270 \\
\hline \multicolumn{10}{|c|}{ c Tabernaemontana coronaria (leaf) n-hexane partition ${ }^{c}$} \\
\hline 1 & 16.882 & $7.578 . E+08$ & 6.91 & $\begin{array}{l}\text { Ibogamine-18-carboxylic acid, } \\
12 \text { methoxy-methyl ester }\end{array}$ & 96 & 48,516 & $510-22-5$ & $\mathrm{C}_{22} \mathrm{H}_{28} \mathrm{~N}_{2} \mathrm{O}_{3}$ & 368 \\
\hline 2 & 13.507 & 3.355.E+ 08 & 3.06 & Phytol & 91 & 14,111 & $150-86-7$ & $\mathrm{C}_{20} \mathrm{H}_{40} \mathrm{O}$ & 296 \\
\hline 3 & 13.458 & 2.298.E +08 & 2.10 & 9,12,15-Octadecatrien-1-ol, (Z,Z,Z) & 93 & 141,196 & $506-44-5$ & $\mathrm{C}_{18} \mathrm{H}_{32} \mathrm{O}$ & 264 \\
\hline 4 & 21.146 & 1.781.E + 08 & 1.63 & $\begin{array}{l}\text { 12-Oelanen-3-yl acetate, (3a) or } \\
\text { Olean-12-en-3-yl acetate }\end{array}$ & 95 & 244,056 & $33,055-28-6$ & $\mathrm{C}_{32} \mathrm{H}_{52} \mathrm{O}_{2}$ & 468 \\
\hline 5 & 16.693 & 1.786.E +08 & 1.63 & Ibogaine & 99 & 131,027 & $83-74-9$ & $\mathrm{C}_{20} \mathrm{H}_{26} \mathrm{~N}_{2} \mathrm{O}$ & 310 \\
\hline 6 & 17.596 & 1.501.E + 08 & 1.37 & Vitamin E or a-Tocopherol & 98 & 151,382 & $59-02-9$ & $\mathrm{C}_{29} \mathrm{H}_{50} \mathrm{O}_{2}$ & 430 \\
\hline 7 & 16.532 & 1.482.E + 08 & 1.35 & $\begin{array}{l}\text { 2H-1-Benzopyran-6-ol, 3,4-dihydro-2,8- } \\
\text { dimethyl-2-(4,8,12-trimethyltridecyl)-, } \\
{\left[2 \mathrm{R}-\left[2 \mathrm{R}^{*}\left(4 \mathrm{R}^{*}, 8 \mathrm{R}^{*}\right)\right]\right]-}\end{array}$ & 95 & 151,380 & 119-13-1 & $\mathrm{C}_{27} \mathrm{H}_{46} \mathrm{O}_{2}$ & 402 \\
\hline 8 & 19.956 & 1.231.E+ 08 & 1.12 & 9,19-Cyclolanost-24-en-3-ol, (3ß) & 98 & 68,266 & 25,692-13-1 & $\mathrm{C}_{31} \mathrm{H}_{52} \mathrm{O}$ & 440 \\
\hline
\end{tabular}

${ }^{a}$ Number of compounds detected: 261; Number of compounds identified: 54

${ }^{b} \mathrm{NA}$ : Not available; Number of compounds detected: 308 ; Number of compounds identified: 36

cNumber of compounds detected: 323 ; Number of compounds identified: 31 


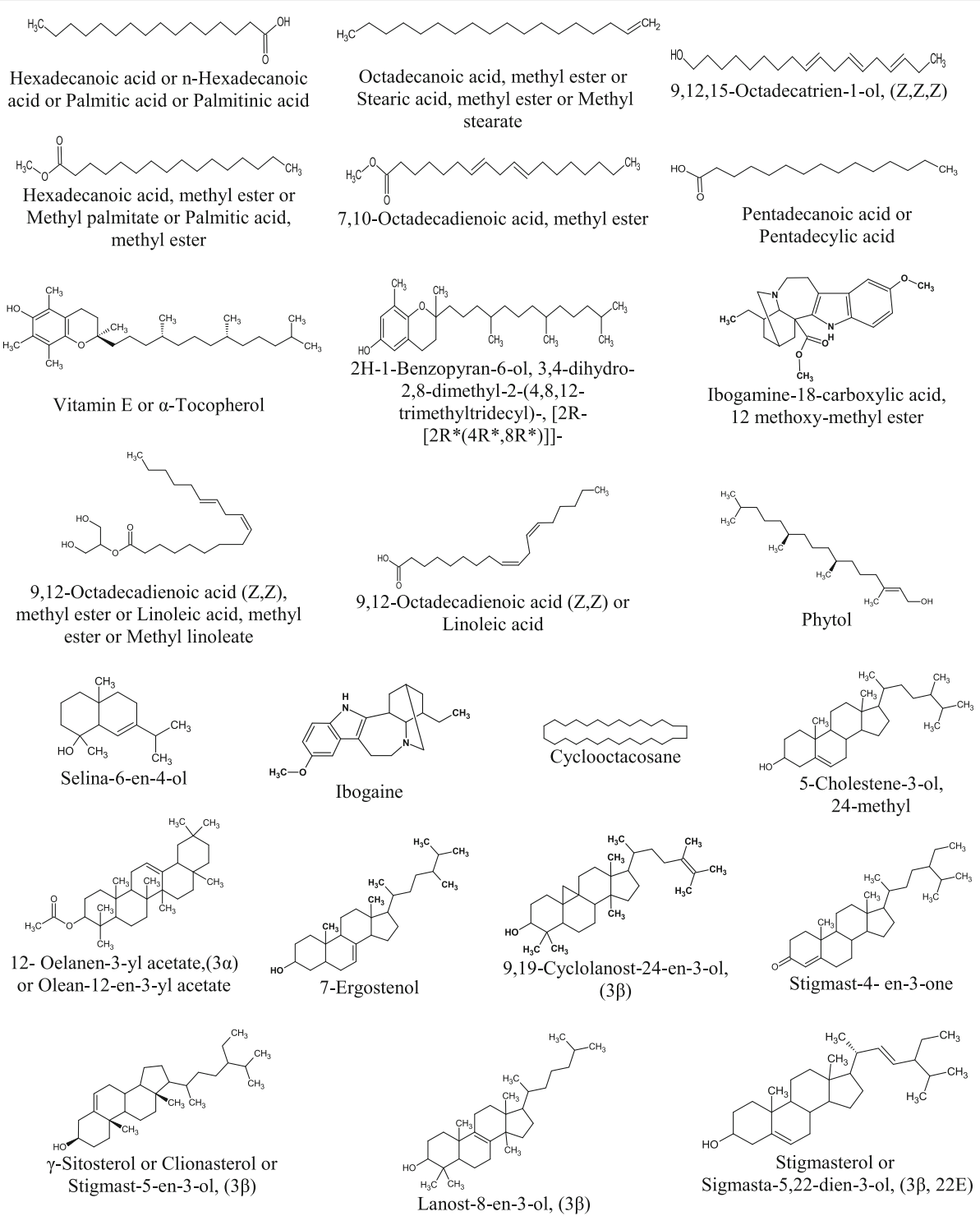

Fig. 2 Molecular structures of major compounds from each plant n-hexane partition based on gas chromatography-mass spectrometry chemometric profiling

dihydro-2,8-dimethyl-2-(4,8,12-trimethyltridecyl)-, [2R$\left.\left[2 R^{*}\left(4 R^{*}, 8 R^{*}\right)\right]\right]-;$ and 9,19-cyclolanost-24-en-3-ol $(3 \beta)$ constituted the major compounds (Table 2c, Fig. 2). The remaining identified compounds were found in trace amounts of $\leq 1.0 \%$ of the total peak area.

\section{Effects of $n$-hexane plant partitions on the growth kinetics of Mycobacterium tuberculosis H37Rv}

The results of this study were expressed as the number of colonies per $\mathrm{mL}$ or $\mathrm{CFU} / \mathrm{mL}$ of $M$. tuberculosis H37Rv over 7-day treatment period as shown in Table 3.

These values were extrapolated as the percentage of colony counts based on the initial counts on Day 0 to show the effects of the partitions on the mycobacterial growth kinetics as illustrated in Fig. 3 and summarised in Table 4.
The results were compared to the negative and positive growth controls. To date, there are no specific guidelines available to rate the cidal activity of mycobacteria and the interpretive criteria of bactericidal activity of antimycobacterial agents are not uniform. In the present study, the results were interpreted based on the definition of cidal or sterilising activity as an effective reduction of the bacterial counts by $\geq 99 \%$ [25-27] and evidence of bactericidal activity as a reduction of colony counts by $\geq 90 \%$ (decrease to $10 \%$ or below of initial count) [28]. Accordingly, in this study, we interpreted final killing effect of $\geq 90 \%$ but $<99 \%$ in the reduction of colony counts as bacteriostatic activity. Figure 3 shows that the untreated control mycobacterial cells underwent three growth phases when introduced into a new culture medium in the absence of anti-TB 
Table 3 Effects of n-hexane plant partitions on the colony counts of Mycobacterium tuberculosis H37Rv over 7-day treatment period

\begin{tabular}{|c|c|c|c|c|c|c|c|c|c|c|c|c|c|c|c|}
\hline \multirow[t]{2}{*}{ Days } & \multicolumn{3}{|c|}{$\begin{array}{l}\text { Control positive } \\
\text { (no drug/extract) }\end{array}$} & \multicolumn{3}{|c|}{$\begin{array}{l}\text { Isoniazid } \\
\text { (MIC: } 0.078 \mu \mathrm{g} / \mathrm{mL} \text { ) }\end{array}$} & \multicolumn{3}{|c|}{$\begin{array}{l}\text { C. speciosus } \\
\text { (MIC: } 100 \text { \%g/mL) }\end{array}$} & \multicolumn{3}{|c|}{$\begin{array}{l}\text { C. citratus } \\
\text { (MIC: } 200 \mu \mathrm{g} / \mathrm{mL} \text { ) }\end{array}$} & \multicolumn{3}{|c|}{$\begin{array}{l}\text { T. coronaria } \\
\text { (MIC: } 100 \mu \mathrm{g} / \mathrm{mL} \text { ) }\end{array}$} \\
\hline & $\begin{array}{l}\text { Mean } \\
\text { CFU/mL }\end{array}$ & $\begin{array}{l}\text { Mean } \% \\
\text { of day } 0\end{array}$ & $\begin{array}{l}\text { Mean \% } \\
\text { STDEV }\end{array}$ & $\begin{array}{l}\text { Mean } \\
\text { CFU/mL }\end{array}$ & $\begin{array}{l}\text { Mean } \% \\
\text { of day } 0\end{array}$ & $\begin{array}{l}\text { Mean \% } \\
\text { STDEV }\end{array}$ & $\begin{array}{l}\text { Mean } \\
\text { CFU/mL }\end{array}$ & $\begin{array}{l}\text { Mean \% } \\
\text { of day } 0\end{array}$ & $\begin{array}{l}\text { Mean \% } \\
\text { STDEV }\end{array}$ & $\begin{array}{l}\text { Mean } \\
\text { CFU/mL }\end{array}$ & $\begin{array}{l}\text { Mean \% } \\
\text { of day } 0\end{array}$ & $\begin{array}{l}\text { Mean \% } \\
\text { STDEV }\end{array}$ & $\begin{array}{l}\text { Mean } \\
\text { CFU/mL }\end{array}$ & $\begin{array}{l}\text { Mean \% } \\
\text { of day } 0\end{array}$ & $\begin{array}{l}\text { Mean \% } \\
\text { STDEV }\end{array}$ \\
\hline 0 & $1.36 \times 10^{6}$ & 100.00 & 0.87 & $1.29 \times 10^{6}$ & 100.00 & 4.56 & $1.86 \times 10^{6}$ & 100.00 & 0.32 & $9.00 \times 10^{6}$ & 100.00 & 5.24 & $4.92 \times 10^{6}$ & 100.00 & 7.19 \\
\hline 1 & $1.48 \times 10^{6}$ & 108.59 & 5.59 & $1.04 \times 10^{6}$ & 80.65 & 1.13 & $8.08 \times 10^{5}$ & 43.60 & 4.37 & $3.58 \times 10^{6}$ & 39.81 & 9.87 & $8.42 \times 10^{5}$ & 17.12 & 4.20 \\
\hline 2 & $2.27 \times 10^{6}$ & 166.87 & 4.16 & $1.80 \times 10^{5}$ & 13.87 & 9.87 & $7.25 \times 10^{5}$ & 39.10 & 8.13 & $1.13 \times 10^{6}$ & 12.59 & 6.24 & $6.17 \times 10^{5}$ & 12.54 & 4.59 \\
\hline 3 & $2.50 \times 10^{6}$ & 184.05 & 0.00 & $1.58 \times 10^{5}$ & 12.26 & 4.47 & $1.35 \times 10^{5}$ & 7.28 & 5.24 & $9.42 \times 10^{5}$ & 10.46 & 1.25 & $5.08 \times 10^{5}$ & 10.34 & 11.59 \\
\hline 4 & $2.71 \times 10^{6}$ & 199.39 & 2.18 & $9.92 \times 10^{4}$ & 7.68 & 5.94 & $1.07 \times 10^{5}$ & 5.75 & 8.84 & $8.75 \times 10^{5}$ & 9.72 & 6.73 & $8.08 \times 10^{4}$ & 1.64 & 1.46 \\
\hline 5 & $3.58 \times 10^{6}$ & 263.80 & 3.29 & $7.92 \times 10^{4}$ & 6.13 & 1.49 & $1.67 \times 10^{2}$ & 0.01 & 0.00 & $5.92 \times 10^{5}$ & 6.57 & 5.98 & $7.83 \times 10^{4}$ & 1.59 & 6.02 \\
\hline 6 & $4.50 \times 10^{6}$ & 331.29 & 5.24 & $6.58 \times 10^{4}$ & 5.10 & 5.37 & $1.67 \times 10^{2}$ & 0.01 & 0.00 & $5.92 \times 10^{5}$ & 6.57 & 1.99 & $4.25 \times 10^{4}$ & 0.86 & 2.77 \\
\hline 7 & $3.08 \times 10^{6}$ & 226.99 & 3.82 & $3.67 \times 10^{4}$ & 2.84 & 12.86 & $1.67 \times 10^{2}$ & 0.01 & 0.00 & $3.83 \times 10^{5}$ & 4.26 & 0.00 & $4.25 \times 10^{4}$ & 0.86 & 2.77 \\
\hline
\end{tabular}

Note: The mean CFU/mL was calculated from two sets of CFU/mL values in triplicate and the mean percentage of standard deviation (STDEV) was calculated based on the differences between two sets of percentage CFU/mL of Day 0

agents. The growth phases comprised of a lag phase from Day 0 to Day 1, a log phase of gradual increase in colony counts from Day 1 to Day 4, an exponential increase from Day 4 to Day 6, and a death phase after Day 6. On the other hand, the control cells treated with isoniazid at its MIC of $0.078 \mu \mathrm{g} / \mathrm{mL}$ showed that on Day 1, the colony counts were decreased by $19.35 \%$ and the time-kill effect of the drug was apparent with a sharp decline by about $86 \%$ of the colony counts on Day 2 (Table 4). On Day 4, the colony counts decreased by $92.32 \%$, showing evidence of mycobactericidal activity ( $\geq 90 \%$ killing). By the end of the study period, a mycobacteriostatic activity of $97.16 \%$ killing was obtained but sterilising activity ( $\geq 99 \%$ killing) was not achieved. Essentially, the effects of stem-rhizome n-hexane partition of $C$. citratus on the growth kinetics of $M$. tuberculosis emulated that of isoniazid (Fig. 3). Similarly, evidence of mycobactericidal activity was observed on Day 4 by a reduction of $90.28 \%$ in the colony counts and sterilising activity was not achieved during the study period
(Table 4). This partition attained mycobacteriostatic activity of $95.74 \%$ killing on Day 7. During the first two days of exposure to $C$. speciosus, the mycobacterial cell population decreased by about $60 \%$ (Fig. 3 and Table 4). Thereafter, exponential bactericidal activity was observed on Day 3 with a sharp decrease in colony counts by $92.72 \%$. By Day 5 , almost all cells were killed (99.99\% killing). Whereas, exposure to $T$. coronaria resulted in immediate exponential bactericidal activity with a sharp decrease of the cell population by $82.88 \%$ on Day 1 (Fig. 3 and Table 4). Evidence of mycobactericidal activity was achieved on Day 3 as shown by a reduction of about $90 \%$ in the colony counts. By Day 6, sterilising activity was achieved (99.14\% killing).

\section{Effects of $n$-hexane plant partitions on the cellular integrity of Mycobacterium tuberculosis H37Rv}

A number of studies have demonstrated the destructive effects of antibiotics and chemical compounds on the mycobacterial cells, describing a variety of morphological

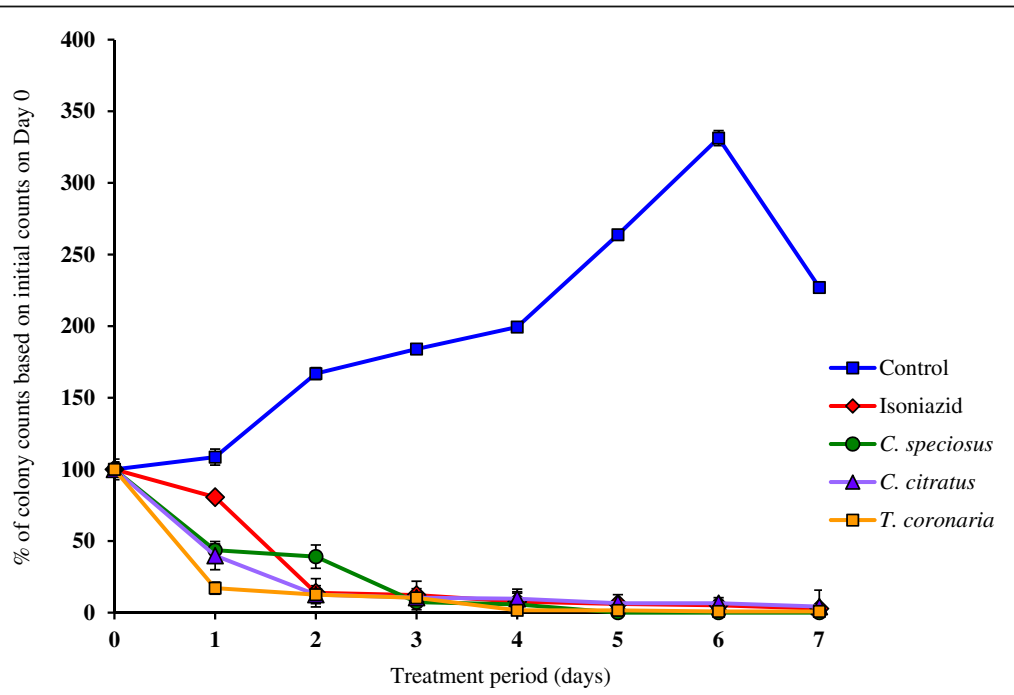

Fig. 3 Effects of n-hexane plant partitions on the growth kinetics of Mycobacterium tuberculosis H37Rv over 7-day treatment period 
Table 4 Overall key effects of n-hexane plant partitions on the growth kinetics of Mycobacterium tuberculosis H37Rv

\begin{tabular}{llllll}
\hline Drug/Plant sp. & MIC $(\mu \mathrm{g} / \mathrm{mL})$ & $\begin{array}{l}\text { Evidence of cidal activity } \\
(\geq 90 \% \text { killing })\end{array}$ & $\begin{array}{l}\text { Cidal activity } \\
(\geq 99 \% \text { killing })\end{array}$ & $\begin{array}{l}\text { Highest killing rate } \\
\text { achieved (\%) }\end{array}$ & Bacteriostatic/bactericidal \\
\hline Isoniazid & 0.078 & Day 4 & Not achieved & 97.16 & Bacteriostatic \\
C. speciosus & 100 & Day 3 & Day 5 & 99.99 & Bactericidal \\
C. citratus & 200 & Day 4 & Not achieved & 95.74 & Bacteriostatic \\
T. coronaria & 100 & Day 3 & Day 6 & 99.14 & Bactericidal \\
\hline
\end{tabular}

defects [29-31]. In the present study, the effects of the active n-hexane partitions of $C$. speciosus, $C$. citratus, and $T$. coronaria at their MIC values on the cellular integrity of M. tuberculosis $\mathrm{H} 37 \mathrm{Rv}$ were observed under SEM to provide physical evidence of cellular changes for the growth study results as described above. The effects of the plant partitions on the cells of $M$. tuberculosis were compared to the effects of the isoniazid-treated and untreated control cells as shown in Fig. 4a-c.

The control cells (Fig. 4a) on Day 3 was a mixture of numerous cells with smooth surface, well defined rigid shape of different morphologies, and some cells with wrinkled surface. Majority of the control cells were mostly rod-like bacilli with septa or constrictions and other types of cell shapes (curve, V or Y-shape) occurred in lower frequency. In addition, some cells were also observed to be conjoined parallel to each other and a few cells had terminal nubs with ridges. Figure $4 \mathrm{~b}$ shows the effects of isoniazid treatment on the integrity of the mycobacterial cells. Figure 4c represents the effects of treatment with the three $\mathrm{n}$-hexane plant partitions as the differences in their individual effects were not discernible. The effects of the plant partitions were generally similar to the isoniazid treatment. However, compared to the control untreated cells, the cells treated with the plant partitions and isoniazid showed significant cellular alterations. After three days of exposures to the partitions and the drug, the cell population consisted of a majority of degraded cells and very few viable cells with smooth surface and rigid outline remained (Fig. $4 \mathrm{~b}$ and $\mathrm{c}$ ). The degraded cells appeared wrinkled, ragged, and shrunk. Tiny holes and dents were also observed on the cell surfaces. Some cells looked like empty shells with hollow ends. Another feature in this study was the observation of patches of amorphous mass of cell debris with "web-like" materials. Slight alterations of the poles of some treated cells were

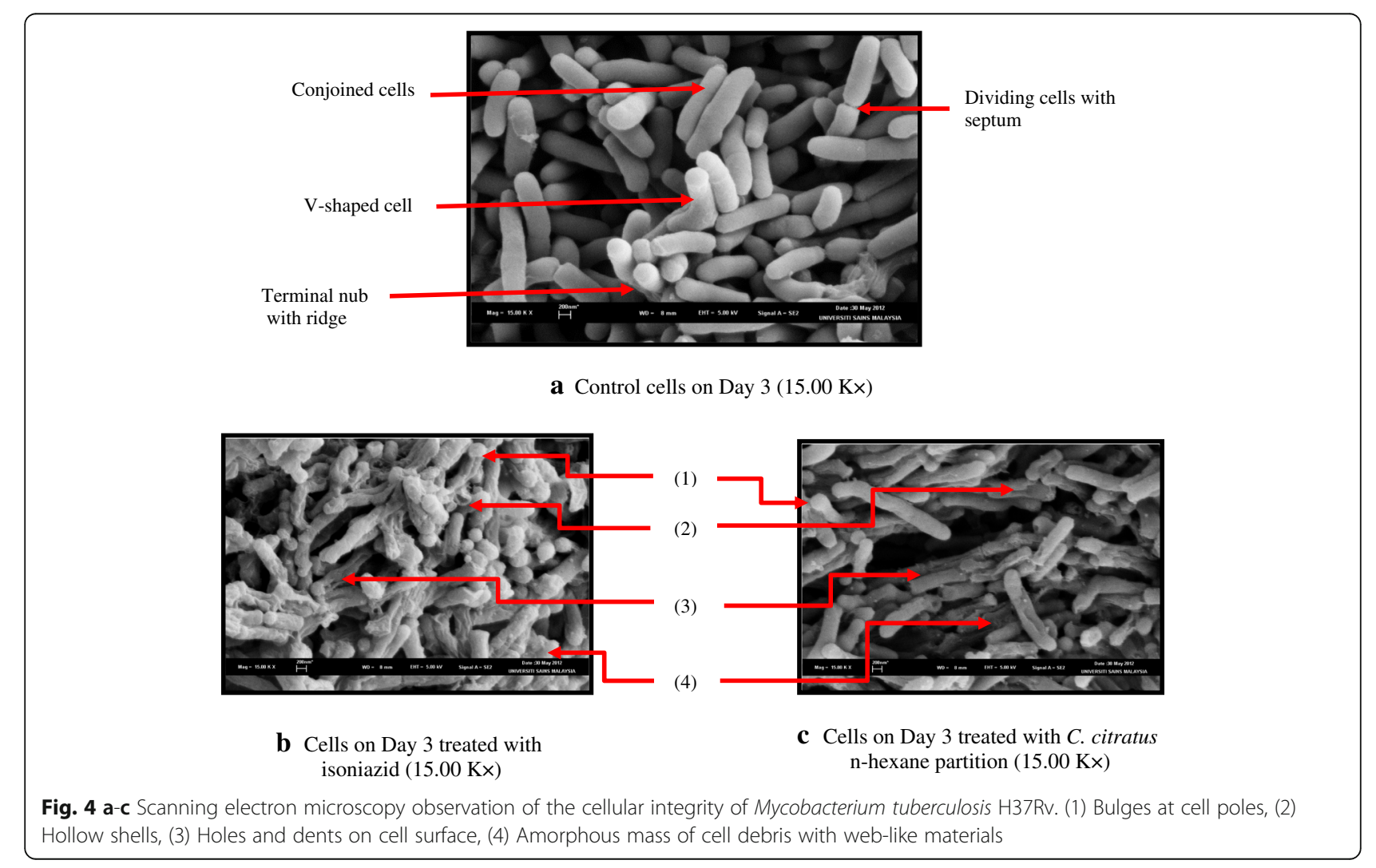


also observed, a feature that was not observed with the control cells. These treated bacilli swelled slightly at either end, so club shape and bulges were observed.

\section{Discussion}

All the plant partition samples were dried thoroughly in an oven at $40{ }^{\circ} \mathrm{C}$ to ensure that any remaining solvent residues evaporated completely. This important step was taken to eliminate the intrinsic toxic effect of the solvents on the test organism, which could interfere with the assay results. All the three test plants exhibited a variety of in vitro anti-TB activity against $M$. tuberculosis H37Rv. Based on their MIC and MBC values, the most active partitions were $\mathrm{n}$-hexane partitions of $C$. speciosus (stem and flower) and T. coronaria (leaf), with promising MIC of $100 \mu \mathrm{g} / \mathrm{mL}$ and MBC of $200 \mu \mathrm{g} / \mathrm{mL}$. These results indicate that these partitions could contain the highest amount of bioactive constituents. The other partition that possessed good anti-TB activity with MIC of $200 \mu \mathrm{g} / \mathrm{mL}$ was C. speciosus chloroform and C. citratus n-hexane. Reviews on anti-TB activity of natural products showed that plant extracts with inhibitory concentrations of $\leq 100 \mu \mathrm{g} / \mathrm{mL}$ have a high potential of containing active phytochemical constituents [32, 33]. However, it is also possible that extracts with MICs of 100-200 $\mathrm{\mu g} / \mathrm{mL}$ could contain promising compounds. Based on the types of solvent, n-hexane produced the highest anti-TB activity, followed by chloroform, and ethyl acetate, indicating that a higher amount of bioactive constituents against $M$. tuberculosis were possibly extracted by the non-polar solvents especially n-hexane. These results agreed with other anti-TB studies of natural products $[34,35]$. Since non-polar solvents are used to solubilise mostly lipophilic compounds such as alkanes, fatty acids, sterols, some terpenoids, alkaloids, and coumarins [36], the results in this study indicate that most of the active constituents could be of lipophilic nature. These results were also supported by the poor activity observed for the polar partitions of methanol, n-butanol and aqueous. It was possible that the bioactive constituents in these partitions could be absent or their amounts were too little to exert inhibitory effects on the mycobacterial cells. Alternatively, since the majority of constituents in these polar solvent partitions were expected to comprise of hydrophilic groups, the molecules could not traverse the lipid layer of the mycobacterial outer membrane. The outer membrane of $M$. tuberculosis is known to present a barrier to the penetration of hydrophilic molecules due to the fact that the cell wall is double-layered, comprising of an inner electron-dense layer of peptidoglycan and an outer electron-transparent layer containing mycolyl arabinogalactan complex covalently bound to the peptidoglycan $[37,38]$. In this study, the potent anti-TB activity of isoniazid (MIC and MBC: $0.078 \mu \mathrm{g} / \mathrm{mL}$ ) was expected in selecting isoniazid as the control drug due its exquisite specificity to $M$. tuberculosis $[39,40]$. It should be noted that the inclusion of this control drug in this study was not to gauge the activity of the plant partitions; rather, it served specifically as a negative growth control to validate the assay procedures together with the positive control.

Gas chromatography-mass spectrometry analysis of the n-hexane partition of each plant revealed a mixture of large number of phytochemicals, of which majority were volatile and semi-volatile organic compounds of lipophilic nature. It must be noted that the numbers of identified compounds and their identities were not absolute for each partition as the results presented in this study were limited and restricted as per the materials utilised and the GC-MS methods employed. The identified compounds, which represented phytochemical classes such as sterol, phenol, diterpene, sesquiterpene, alkaloid, triterpenoid, fatty acid, and tocopherol were also commonly isolated in antitubercular plants [41-43]. The lipophilic nature of the compounds was an important property of the bioactive constituents in these plant partitions as they could penetrate the hydrophobic outer membrane of $M$. tuberculosis to exert inhibitory effects. The identification of these compounds supported the higher anti-TB activity of the non-polar solvent partitions as discussed above. Ideally, the specific bioactive constituents should be isolated and elucidated. At present we are working with our research collaborators to further isolate and elucidate these constituents, which require an arduous lengthy chemical-biological approach. Nevertheless, with the recent availability of a number of modern sophisticated hyphenated separation and spectroscopic techniques, their isolation and elucidation should become much easier. With the isolation of these active constituents, further assays could be carried out to identify the mechanism of their actions on the tubercle cells.

The active n-hexane partitions of $C$. speciosus, $C$. citratus, and $T$. coronaria were further investigated to provide an insight into the killing dynamics of these partitions at their respective MIC values by assessing the mycobacterial killing at different time-points during their exposures. As exposure of the mycobacterial population to maximum achievable drug concentrations in vivo lasts for only a very short period [26], the in vitro endpoint assay approach of $\mathrm{MIC}$ and $\mathrm{MBC}$ determinations could not reflect the actual events during infection. Therefore, to emphasise the susceptibility results, inhibition rate of the mycobacterial growth was also assessed. Moreover, according to the recommendation by the National Committee for Clinical Laboratory Standards (NCCLS), a time factor should be included in antimicrobial susceptibility methods because the rate of killing has more clinical significance than the degree of killing [44]. Particularly, during M. tuberculosis 
initial infection, the antimicrobial killing rate in relation to the time of exposure is an important characteristic for therapeutic efficacy to prevent development of resistance [27]. In this study, the growth features of consecutive lag, log, and death phases exhibited by the untreated control mycobacterial cells were typical of the normal growth of Mycobacterium species when introduced into a new medium $[27,45,46]$. Concerning the treatment with isoniazid, even though sterilising activity ( $\geq 99 \%$ killing) was not achieved, less than $3 \%$ of the mycobacterial cell population remained viable by the end of the study period, indicating a strong mycobacteriostatic activity. This result concurred with previous findings that isoniazid is mycobacteriostatic against $M$. tuberculosis at lag or initial phase as opposed to log phase, during which, it is mycobactericidal $[28,47]$. In this present study, it was expected that the mycobacterial cell population was still undergoing lag phase of growth since the starting inoculum was at lag phase. The mycobacteriostatic activity of stem-rhizome nhexane partition of $C$. citratus on $M$. tuberculosis was comparable to isoniazid. However, it was possible that this partition and isoniazid could likely exert higher cidal activity on the lag phase cells over a longer exposure period and that its bactericidal activity was time-dependent. This possibility should be considered for future investigations. The high and rapid killing rates of the $\mathrm{n}$-hexane partitions of $C$. speciosus and $T$. coronaria on the tubercle cells indicate that these plant partitions could contain effective anti-TB agents with high bactericidal capacity. Anti-TB agents with sterilising activity by killing all remaining viable bacilli are desirable to prevent relapse and hence, reduce the risk of resistance development [9]. It should be noted that these two partitions also exhibited good MIC $(100 \mu \mathrm{g} / \mathrm{mL})$, and MBC $(100-200 \mu \mathrm{g} / \mathrm{mL})$ values, which were evaluated on the mycobacterial cells using inoculum at log phase of growth. Hence, the results in this study also indicate that these plant partitions were effective against the mycobacterial cells during both lag and log phases of growth.

Observation under SEM showed that majority of untreated control tubercle cells on Day 3 of growth had smooth surface and well-defined rigid shape of different morphologies indicating that they were healthy and viable. The presence of some cells with wrinkled surface could be the leftover old cells in the inoculum. The cell population had been shown to undergo log phase of growth on Day 3 (Fig. 3). The exponential growth stage was supported by the presence of many bacilli with constrictions or septa in the control cells, which indicate that these cells were dividing and undergoing active proliferation. According to previous reports [48, 49], the septa could be formed through an inward growth of cytoplasmic membrane and cell wall materials, which eventually closed off the cytoplasmic compartments of each daughter cell. Finally, part of the peptidoglycan that held the two cells together was hydrolysed to physically separate the cells $[50,51]$. The curve or V-shape of the mycobacterial bacilli could be caused by post-fission snapping movements as suggested by related studies [52-54]. In the present study, these V-forms were probably temporal structures since very few of these cells were observed, which agreed with the observations made by a previous study [52] on the electron microscopy analysis of $M$. tuberculosis cell division. The study also reported similar observation of the presence of external ridges at the proximal ends of the mycobacterial cells and suggested that these ridges could be the original site of division. After the two daughter cells split, the site of division could continue to grow, forming a nub at the end of the cell. Concerning the parallel-conjoined cells in pairs, an early report [55], suggested that they could be formed due to the growth of a daughter cell budding from the side of the mother cell and its subsequent growth along the side of the mother cell before splitting into two separate cells. In the present study, the damaging effects of isoniazid and the plant partitions on the cellular integrity of $M$. tuberculosis were shown by the observation of a variety of morphologies with evidences of structural changes. Majority of the treated cell population were degraded cells with wrinkled, ragged, and shrunk surfaces indicating dilapidation of the overall cell structure. The presence of tiny holes and dents on the cell surfaces could be due to the lethal effects of the plant partitions and isoniazid, which caused the cellular contents or cytoplasmic materials to leak out from the cells. Some cells that appeared like empty shells with hollow ends could be the eventual effect when all the cytoplasmic materials extruded out, indicating loss of viability. In a related study [29], it was observed that the extrusion of cellular contents of M. tuberculosis H37Ra cells exposed to isoniazid eventually caused the cell structure to collapse. The report suggested that the extrusion of cellular contents or cytoplasmic materials from the cells could be the rationale for the formation of the "web-like" materials, which were also observed around the cells in this study. These in turn might cause the cells to clump together, as shown by the presence of patches of amorphous mass of cell debris. These extracellular materials could probably be alkali-extractable polysaccharides being released into the external medium by treated mycobacterial cells as reported by an early study [56] on the effects of isoniazid. Alternatively, according to another study [57], the materials could be composed mainly of proteins, which were over-secreted following the action of the same drug. The study suggested that this effect caused the cells to shrink and eventually, these deformed cells aggregated into an amorphous mass of cell debris. The last cellular feature 
observed in this present study was slight swelling of the poles of some treated cells, which made them appear as club-shape and bulges. This feature was also observed in a related study [58]. The study suggested that it could be attributed to the ability of the mycobacterial bacilli to survive environmental hardship or the morphological changes probably started at the bacterial poles, which represent the weaker regions of the growing cells.

\section{Conclusions}

The n-hexane partition of the plant materials exhibited the highest inhibitory activity against $M$. tuberculosis H37Rv indicating that the active phytochemical constituents could be of lipophilic nature. This indication was supported by the identification of many lipophilic constituents in the partitions using GC-MS analysis. The high killing rate over time shown by the n-hexane partitions of $C$. speciosus stem-flower and T. coronaria leaf indicates that the active constituents in these plant partitions could serve as sterilising agents against the mycobacterial cells during both lag and log phases of growth. The mycobacteriostatic activity of n-hexane partition of $C$. citratus stem-rhizome was comparable to isoniazid and its mycobactericidal activity could be time-dependent. Finally, the lethal effects of all the $n$-hexane plant partitions altered the normal mycobacterial cellular structure and caused cell lysis, thus, prevented proliferation of the cells.

\section{Abbreviations}

ADC: Albumin, dextrose and catalase; ATCC: American Type Culture Collection; CFU: Colony forming unit; $\mathrm{CO}_{2}$ : Carbon dioxide; DMSO: Dimethyl sulphoxide; HMDS: Hexamethyldisilazane; MB: Middlebrook; MBC: Minimum bactericidal concentration; MIC: Minimum inhibitory concentration; OADC: Oleic acid, albumin, dextrose and catalase; PBS: Phosphate-buffered saline; SEM: Scanning electron microscope; TB: Tuberculosis; WHO: World Health Organisation

\section{Acknowledgements}

The authors acknowledge the contributions of the technical personnel of Herbarium Unit and Electron Microscope Unit of School of Biological Sciences, USM for their assistance.

\section{Funding}

We wish to thank Universiti Sains Malaysia for funding this research project through RU Grant: 1001/PBIOLOGI/811310 and Short-term Grant: 304/PBIOLOGI/6312004). The funder had no role in the study design, data collection, and analysis or preparation of the manuscript.

\section{Availability of data and materials}

The datasets for supporting the outcomes of the study are included in the article.

\section{Authors' contributions}

SM participated in all aspects of the study and drafted the manuscript. HAW, $\mathrm{Pl}$, and $\mathrm{HO}$ evaluated the manuscript. NNI and TP assisted the in vitro assays. All authors have read and approved the final manuscript.

\section{Ethics approval and consent to participate}

Not applicable.

\section{Consent for publication}

Not applicable.

\section{Competing interests}

The authors declare that they have no competing interests.

\section{Publisher's Note}

Springer Nature remains neutral with regard to jurisdictional claims in published maps and institutional affiliations.

\section{Author details}

${ }^{1}$ School of Biological Sciences, Universiti Sains Malaysia, 11800 Minden, Pulau Pinang, Malaysia. ${ }^{2}$ School of Pharmaceutical Sciences, Universiti Sains Malaysia, 11800 Minden, Pulau Pinang, Malaysia. ${ }^{3}$ School of Chemical Sciences, Universiti Sains Malaysia, 11800 Minden, Pulau Pinang, Malaysia.

Received: 20 July 2017 Accepted: 29 December 2017

Published online: 08 January 2018

\section{References}

1. Lawn SD, Zumla Al. Tuberculosis. Lancet. 2011;378(9785):57-72.

2. Stop TB Partnership. End TB infographic: General facts and information 2016. http://www.stoptb.org/events/world_tb_day/2016/assets/docs/EndTB_ Infographic_GENERAL.jpg. Accessed 20 Dec 2016.

3. World Health Organisation. Global tuberculosis report 2016. 2016. http:// www.who.int/tb/publications/global_report/en/. Accessed 20 Dec 2016.

4. Gandhi NR, Nunn P, Dheda K, Schaaf HS, Zignol M, van Soolingen D, Jensen $P$, Bayona J. Multidrug-resistant and extensively drug-resistant tuberculosis: a threat to global control of tuberculosis. Lancet. 2010;375:1830-43.

5. O'Brien RJ, Nunn PP. The need for new drugs against tuberculosis. Obstacles, opportunities, and next steps. Am J Respir Crit Care Med. 2001;163(5):1055-8.

6. Sacks LV, Behram RE. Challenges, successes, and hopes in the development of novel TB therapeutics. Future Med Chem. 2009:1(4):749-56.

7. Verpoorte R. Exploration of nature's chemodiversity: the role of secondary metabolites as leads in drug development. Drug Discov Today. 1998:3:232-8.

8. Aiyegoro OA, Okoh Al. Use of bioactive plant products in combination with standard antibiotics: implications in antimicrobial chemotherapy. J Med Plants Res. 2009;3(13):1147-52.

9. World Health Organisation. Treatment of tuberculosis: guidelines. 2010. http://whqlibdoc.who.int/publications/2010/9789241547833_eng.pdf. Accessed 15 Dec 2011

10. Chin WY. A guide to medicinal plants. Singapore: Singapore Science Centre; 2002.

11. Chooi $\mathrm{OH}$. Tumbuhan liar, khasiat ubatan dan kegunaan lain. Kuala Lumpur: Utusan Publications and Distributors Sdn Bhd; 2004.

12. Chee BJ. Susun kelapa antara penawar dan racun. 2013. http://www. academia.edu/2977521/Susun_Kelapa_Antara_Penawar_dan_racun. Accessed 10 Jun 2013

13. Saraf A. Phytochemical and antimicrobial studies of medicinal plant Costus speciosus (Koen.) E-J. Chem. 2010;7(S1):S405-13.

14. Shah G, Shri R, Panchal V, Sharma N, Singh B, Mann AS. Scientific basis for the therapeutic use of Cymbopogon citratus, Stapf (lemon grass). J Adv Pharm Technol Res. 2011;2(1):3-8.

15. Abubakar IB, Loh HSA. Review on ethnobotany, pharmacology and phytochemistry of Tabernaemontana corymbosa. J Pharm Pharmacol. 2016:68(4):423-32.

16. Mohamad S, Zin NM, Wahab HA, Ibrahim P, Sulaiman SF, Zahariluddin ASM, Noor SSMN. Antituberculosis potential of some ethnobotanically selected Malaysian plants. J Ethnopharmacol. 2011;133:1021-6.

17. Jones WP, Kinghorn AD. Extraction of plant secondary metabolites. Methods Mol Biol. 2012;864:341-66.

18. Caviedes L, Delgado J, Gilman RH. Tetrazolium microplate assay as a rapid and inexpensive colorimetric method for determination of antibiotic susceptibility of Mycobacterium tuberculosis. J Clin Microbiol. 2002:40(5):1873-4.

19. Marshall NJ, Goodwin CJ, Holt SJ. A critical assessment of the use of microculture tetrazolium assays to measure cell growth and function. Growth Regulat. 1995:5(2):69-84.

20. Berridge MV, Herst PM, Tan AS. Tetrazolium dyes as tools in cell biology: new insights into their cellular reduction. Biotechnol Annu Rev. 2005;11:127-52.

21. Clinical and Laboratory Standards Institute (CLSI). Methods for determining bactericidal activity of anti-microbial agents. In: Wayne, editor. Approved guideline, CLSI document M26-A. Pennsylvania: CLSI; 1998.

22. Tayade AB, Dhar P, Kumar J, Sharma M, Chauhan RS. Chemometric profile of root extracts of Rhodiola imbricata Edgew. With hyphenated gas 
chromatography mass spectrometric technique. PLoS One. 2013; https://doi.org/10.1371/journal.pone.005.

23. Mohamad S, Ibrahim P, Sadikun A. Susceptibility of Mycobacterium tuberculosis to isoniazid and its derivative, 1-isonicotinyl-2-nonanoyl hydrazine: investigation at cellular level. Tuberculosis. 2004;84:56-62.

24. Hoben HJ, Somasegaran P. Comparison of pour, spread and drop plate methods for enumeration of Rhizobium spp. in inoculants made from presterilised peat. Appl Environ Microbiol. 1982;44:1246-7.

25. Heifets L, Lindholm-Levy P. Comparison of bactericidal activities of streptomycin amikacin, kanamycin, and capreomycin against Mycobacterium avium and Mycobacterium tuberculosis. Antimicrob Agents Ch. 1989;33(8):1298-301.

26. Bakker-Woudenberg IAJM, van Vianen W, van Soolingen D, Henri AV, van Agtmael MA. Antimycobacterial agents differ with respect to their bacteriostatic versus bactericidal activities in relation to time of exposure, mycobacterial growth phase, and their use in combination. Antimicrob Agents Ch. 2005;49(6):2387-98.

27. de Steenwinkel JEM, De Knegt GJ, Ten Kate MT, Van Belkum A, Verbrugh HA, Kremer K, Van Soolingen D, Bakker-Woudenberg IAJM. Time-kill kinetics of antituberculosis drugs, and emergence of resistance, in relation to metabolic activity of Mycobacterium tuberculosis. J Antimicrob Chemoth. 2010;65(12):2582-9.

28. Yamori S, Ichiyama S, Shimokata K, Tsukamura M. Bacteriostatic and bactericidal activity of antituberculosis drugs against Mycobacterium tuberculosis, Mycobacterium avium-Mycobacterium intracellulare complex and Mycobacterium kansasii in different growth phases. Microbiol Immunol. 1992;36:361-8.

29. Takayama K, Wang L, Merkal RS. Scanning electron microscopy of the H37Ra strain of Mycobacterium tuberculosis exposed to isoniazid. Antimicrob Agents Ch. 1973;4:62-5.

30. van Boxtel RM, Lambrecht RS, Collins MT. Effects of polyoxyethylene sorbate compounds (tweens) on colonial morphology, growth, an ultrastructure of Mycobacterium paratuberculosis. Acta Pathol Microbiol Immunol Scand. 1990;98:901-18.

31. Verbelen C, Dupres V, Menozzi FD, Raze D, Baulard AR, Hols P, Dufrenel YF. Ethambutol-induced alterations in Mycobacterium bovis BCG imaged by atomic force microscopy. FEMS Microbiol Lett. 2006;264(2):192-7.

32. Newton SM, Lau C, Wright CWA. Review of antimycobacterial natural products. Phytother Res. 2000;14:303-22.

33. Okunade AL, Elvin-Lewis MP, Lewis WH. Natural antimycobacterial metabolites: current status. Phytochemistry. 2004;65(8):1017-32.

34. Mmushi TJ, Masoko P, Mdee LK, Mokgotho MP, Mampuru LJ, Howard RL. Antimycobacterial evaluation of fifteen medicinal plants in South Africa. Afr J Trad. 2010;7(1):34-9.

35. Luo X, Pires D, Ainsa J, Gracia B, Mulhovo S, Duarte A, Anes E, Ferreira MJ. Antimycobacterial evaluation and preliminary phytochemical investigation of selected medicinal plants traditionally used in Mozambique. J Ethnopharmacol. 2011;37:114-20.

36. Otsuka H. Purification by solvent extraction using partition coefficient. In Sarker SD, Latif Z, Gray Al, editors. Methods in biotechnology: natural product isolation. 2nd edn. New Jersey: Humana Press; 2006. p. 269-74.

37. Brennan PJ. Structure, function, and biogenesis of the cell wall of Mycobacterium tuberculosis. Tuberculosis. 2003:83:91-7.

38. Alderwick L, Harrison J, Lloyd GS, Birch HL. The mycobacterial cell wallpeptidoglycan and arabinogalactan. Spring Harb Perspect Med. 2015:5:a021113.

39. Zhang Y, Young D. Molecular genetics of drug resistance in Mycobacterium tuberculosis. J Antimicrob Chemoth. 1994;34:313-39.

40. Smith T, Wolff KA, Nguyen L. Molecular biology of drug resistance in Mycobacterium tuberculosis. Curr Top Microbiol Immunol. 2013;374:53-80.

41. Copp BR. Antimycobacterial natural products. Nat Prod Rep. 2003;20:535-57.

42. Copp BR, Pearce AN. Natural product growth inhibitors of Mycobacterium tuberculosis. Nat Prod Rep. 2007;24(2):278-97.

43. Samarth RM, Samarth M, Matsumoto Y. Medicinally important aromatic plants with radioprotective activity. Future Science OA. 2017;3(4) doi:https://doi.org/10.4155/fsoa-2017-0061.

44. National Committee for Clinical Laboratory Standards (NCCLS). In: Wayne, editor. Susceptibility testing of mycobacteria, nocardia, and other aerobic actinomycetes; tentative standard M24-T2. 2nd ed. Philadelphia: NCCLS; 2000.

45. Andersen P, Askgaard D, Ljungqvist L, Bennedsen J, Heron I. Proteins released from Mycobacterium tuberculosis during growth. Infect Immun. 1991;59(6):1905-10

46. Mohamad S, Ibrahim P, Wahab HA. Effects of isoniazid on viability, cell morphologies and acid fastness properties of Mycobacterium avium NCTC 8559 during the growth cycle. Chemotherapy. 2007;53:263-6.
47. Takayama K, Wang L, David HL. Effect of isoniazid on the in vivo mycolic acid synthesis, cell growth, and viability of Mycobacterium tuberculosis. Antimicrob Agents Ch. 1972;2(1):29-35.

48. Harry EJ. Bacterial cell division: regulating Z-ring formation. Mol Microbiol. 2001;40:795-803.

49. Errington J, Daniel RA, Scheffers DJ. Cytokinesis in bacteria. Microbiol Mol Biol Rev. 2003;67:52-65.

50. Buddelmeijer N, Beckwith J. Assembly of cell division proteins at the E. coli cell centre. Curr Opin Microbiol. 2002:5:553-7.

51. Margolin W. Bacterial division: another way to box in the ring. Curr Biol. 2006;16:R881-4

52. Dahl JL. Electron microscopy analysis of Mycobacterium tuberculosis cell division. FEMS Microbiol Letters. 2004;240:15-20.

53. Farnia P, Masjedi MR, Farnia P, Merza MA, Tabarsi P, Zhavnerko GK, Ibrahim TA, Kuan HO, Ghanavei J, Farnia P, Ranjbar R, Poleschuyk NN, Titov LP, Owlia P, Kazampour M, Setare M, Sheikolslami M, Migliori GB, Velayati AA. Growth and cell division in extensive (XDR) and extremely drug resistant (XXDR) tuberculosis strains: transmission and atomic force observation. Int J Clin Exp Med. 2010;3:320-6.

54. Malhotra S, Bhatia NK, Kaushal M, Kaur N, Chauhan A. Pleomorphic appearance in Mycobacterium tuberculosis. J Public Health Epidemiol. 2010;2:11-2.

55. Chatterjee KR, Gupta NND, De ML. Electron microscopic observations on the morphology of Mycobacterium leprae. Exp Cell Res. 1959;18:521-7.

56. Winder FG, Rooney SA. The effects of isoniazid on the carbohydrates of Mycobacterium tuberculosis BCG. Biochem J. 1970;177:355-68.

57. Bardou F, Quemard A, Dupont M, Horn C, Marchal G, Daffe M. Effects of isoniazid on ultrastructure of Mycobacterium aurum and Mycobacterium tuberculosis and on production of secreted proteins. Antimicrob Agents Ch. 1996:40:2459-67.

58. Velayati AA, Farnia P. Morphological characterisation of Mycobacterium tuberculosis. In: Cardona PJ, editor. Understanding tuberculosis - deciphering the secret life of the bacilli. Croatia: InTech Publisher; 2012. p. 149-66.

\section{Submit your next manuscript to BioMed Central and we will help you at every step:}

- We accept pre-submission inquiries

- Our selector tool helps you to find the most relevant journal

- We provide round the clock customer support

- Convenient online submission

- Thorough peer review

- Inclusion in PubMed and all major indexing services

- Maximum visibility for your research

Submit your manuscript at www.biomedcentral.com/submit
) Biomed Central 